\title{
Growing Fusion of Populism and Euroscepticism in Italy: A Comparative Analysis of the League and The Five Star Movement
}

\author{
Selcen Öner \\ Bahcesehir University (Turkey)
}

There has been a growing fusion of populism and Euroscepticism in European politics, especially after recent economic and migration crises. Despite being a founding $E U$ member and one of the most Europhile countries, Italy has seen the simultaneous rise of populism and Euroscepticism, especially after the last national elections in 2018. After introducing its conceptual and analytical framework, based on the growing fusion of populism and Euroscepticism, this article compares the
League and the Five Star Movement (M5S) in terms of populism and Euroscepticism and their policies before the last European Parliament elections in 2019. The qualitative analysis is based on semi-structured, face-to-face, indepth interviews with elite and expert participants conducted by the author in Italy in 2018.

Keywords: populism, Euroscepticism, Italy, The League, The Five Star Movement, European Parliament Elections.

$\mathrm{P}$ opulism and Euroscepticism have increasingly fused in European politics, especially since recent economic and migration crises (Mudde, 2004; Leconte, 2015). Despite being a founding EU member and one of the most Europhile countries, Italy has seen the simultaneous rise of populism and Euroscepticism, particularly since the last national elections in March 2018. Two populist and Eurosceptic parties, the League (Lega) and the Five Star Movement (Movimento Cinque Stelle, M5S) formed a coalition government in June 2018 under the leadership of Guiseppe Conte.

Caiani and Graziano (2016: 243-262) argue that all Italian parties have shown some signs of populism over recent decades. This intensification of populist characteristics is closely linked to the economic crisis and the 
government's response. The degree of populism exhibited by Italian political parties has grown, especially in terms of rhetoric and communication style. The Northern League (Lega Nord-LN) has been the most populist Italian party across four dimensions: political rhetoric, ideology, type of organization and style of communication. They note that the LN showed fewer populist characteristics in 2009, which confirms the "fringe party Euroscepticism hypothesis' (Taggart, 1998) according to which parties become less Eurosceptic in government.

Caiani and Graziano (2016: 262-263) argue that the economic crisis triggered the consolidation of populist characteristics. In particular, M5S would have never become so successful without the crisis. The migration crisis was also perceived as connected with EU institutions and EU elites. This has accelerated and fused rising populism and Euroscepticism. McDonnell and Werner (2019: 1762) revealed that populist radical right parties and their supporters share much closer positions on anti-immigration than European integration.

In the populist tradition in Italian political culture, charismatic leadership is crucial. The populism of Forza Italia (FI) and LN reflects the new wave of populist movements that have developed on the European right since the 1980s (Fella and Ruzza, 2013: 38-43). As Kneuer (2018: 2) argues, not all Eurosceptic parties are populist, nor is every populist party Eurosceptic. The more the permissive consensus on European integration erodes, the more that populists have seized the opportunity to exploit this public perception.

Three main theoretical approaches have been adopted to explain Euroscepticism. The first focuses on economic factors, while the second focuses on how Europeans perceive their identity (civic versus ethnic). The last focuses on the institutional factor of citizens' distrust of national and European institutions (Hooghe and Marks, 2007). Populism, meanwhile, can also be explained in terms of economic and cultural factors (Kneuer, 2018: 2; Inglehart and Norris, 2016) while another common characteristic of populism and Euroscepticism is anti-elitism. Thus, studies of populism and Euroscepticism intersect (Kneuer, 2018: 2).

Drawing on this literature, this article hypothesizes that Europe's economic and migration crises have fuelled Euroscepticism and populism. Interacting and fusing with each other, these growing ideologies have influenced Italian politics due to economic insecurity and cultural anxieties. This hypothesis is tested through a comparative analysis of the League and the M5S.

After introducing the conceptual analysis and theoretical framework based on the growing fusion of populism and Euroscepticism, article explains the methodology. It then analyzes the data from 22 semi-structured, in-depth, face-to-face expert and elite interviews, conducted in Italy in 2018. The article compares the League and the M5S in terms of Euroscepticism and types of populism while considering their policies before the last European Parliament (EP) elections in May 2019. 


\section{CONCEPTUAL ANALYSIS AND ANALYTICAL FRAMEWORK: GROWING FUSION OF POPULISM AND EUROSCEPTICISM} right in Europe. Mudde (2007: 1) argues that "the populist radical right is the only successful new party family in Europe". The common ideological characteristics of this party family are nationalism, xenophobia, welfare chauvinism, a strong state and traditional ethics. Opposition to the EU and globalization have also become crucial elements for the new radical right as well (Mudde, 2007). Rightwing exclusionary versions of populism usually rely on nativism, which refers to a narrow ethnic understanding of who the members of "the true people" are (Mudde and Kaltwasser, 2018: 1669). Mudde (2007: 19) defines "nativism" as an "ideology that holds that states should be inhabited exclusively by members of the nation and that non-native elements are fundamentally threatening to the homogeneous nation-state".

There are various approaches to populism. Firstly, it can be considered as an ideology focusing on the virtues of the "people" against the "establishment"; secondly, it can be a rhetoric that legitimizes new political actors while delegitimizing the old ones; thirdly, it is considered as an informal communication style that offers easy solutions to complex problems; lastly, it is seen as an organization based on the concentration of party power in the hands of a leader and the personalisation of the party (Caiani and Graziano, 2016: 245).

The two theses of "cultural backlash" and "economic anxiety" come from the literature on populist radical right parties that combine populism, nativism, and authoritarianism. For example, the populist radical right derives its xenophobic tendencies from its nativism rather than its populism. Populist radical right parties usually have a nativist agenda in contrast to populist radical left equivalents, such as Podemos (Mudde and Kaltwasser, 2018: 1673-1678). M5S, which claims to be neither right nor left, also lacks a nativist agenda.

"Losers of globalization" thesis (Ford and Goodwin, 2013; cited by Mudde and and Kaltwasser, 2018: 1674) is a combination of the economic anxiety and cultural backlash approaches. This thesis explains electoral support for populist radical right parties by the "cultural framing of economic anxiety" (Mudde and Kaltwasser, 2018: 1674).

Europe's multiple crises over the last decade, particularly the economic and migration crises have all critically influenced the rise of populism and Euroscepticism (Kneuer, 2018: 1-4). Since populist parties usually perceive the EU as a Trojan horse of globalization, they share Eurosceptic mobilization strategies (Ivaldi, Lanzone, and Woods, 2017: 369). Prior to the Maastricht Treaty, Eurosceptism was usually considered as marginal and largely confined to radical parties. However, recent crises have made European issues central in the domestic politics (Taggart and Szczerbiak, 2013: 17). 
Bardi (2014: 358) suggests an additional specific type of Euroscepticism, which he calls "horizontal Euroscepticism" that has become more common since the economic crisis. It manifests itself in statements and actions that express negative attitudes towards other member states by citizens, political parties or political actors. Although not directly aimed at the EU, it can make citizens' perceptions of and attitudes towards it more negative. After the economic crisis, for example, many Italians blamed Germany specifically for austerity policies (Corbetta and Vignati, 2014: 54). It was then directed towards France after the migration crisis through M5S and the League's horizontal Eurosceptic discourse focusing on France and French President Emmanuel Macron in the lead up to the 2019 EP elections.

Thus, the significant harm that Italy has suffered from the economic and migration crises has provided the ideal circumstances for the League to exploit for "cultural framing of economic anxiety" using nativist rhetoric. M5S, on the other hand, has usually focused on economic anxiety. This article therefore compares the two political parties in terms of their populism and Euroscepticism prior to the 2019 European Parliament elections.

\section{THE METHODOLOGY}

This study used qualitative methodology, specifically the case study method, to compare the two cases of the League and M5S. Qualitative methodology accepts a smaller $\mathrm{N}$ and often relies on detailed knowledge of a small number of cases (Elman, 2008: 274). Gerring (2004: 341) defines a case study as an "in-depth study of a single unit where the scholar's aim is to elucidate features of a larger class of similar phenomena".

Accordingly, this study analyzed two Italian political parties, the League and M5S, in terms of the growing fusion of populism and Euroscepticism, especially since Europe's economic and the migration crises.

The fieldwork was conducted in Italy by the author between 17 September and 7 December 2018. The face-to-face, semi-structured, in-depth interviews were mostly conducted in Rome, but also in Florence and Pisa. The interviewees were academics and experts from think tanks specializing in populism, Euroscepticism, and Italian politics, a journalist who wrote a book on populism in Italy, and one member of the League from the Chamber of Deputies. Two Skype interviews were also conducted in January 2019: one with an academic from Milan and another with a member of the European Parliament (MEP) from Italy, from the Progressive Alliance of Socialists and Democrats parliamentary group.

The biggest challenge during the fieldwork was the language barrier as the interviews were conducted in English. The author tried to contact members of the League and the M5S from the Chamber of Deputies through their official e-mails. However, there was only one positive response from a League member from the Chamber of Deputies. Populism is a sensitive issue for both parties, which probably made it harder to find interviewees.

As Interviewee 4 (2018) argued, "interviewing the M5S... is extremely difficult". She continued, "for my research project, I spent a lot of energy... I used all my 
contacts and I had only 4 interviews". According to Interviewee 16 (2018), M5S usually avoid interviews because they are young and inexperienced. However, she added that, compared to the League, M5S is more open to consultation about specific policies with experts and think tanks. Interviewee 13 (2018) argued that M5S is willing to listen to think tanks and engage in dialogue whereas the League is less interested. This greater need to consult may reflect M5S's less experience.

Further research is needed through different case studies and comparative analyses to evaluate the fusion of populism and Euroscepticism in Europe, and identify its causes and varieties. This will enable countries to cope better with current challenges in European politics and ensure the future of the EU project.

\section{THE LEAGUE}

LN which was primarily a "regionalist populist" party (McDonnell, 2006: 127) was established in northern Italy in 1991. In contrast with its earlier pro-European stance, it developed a clear Eurosceptic position by the mid-1990s (Taggart and Szczerbiak, 2013: 27).

Under Matteo Salvini's leadership since 2013, LN has transformed itself into a populist radical right party while it stopped referring to the North in its name in 2014 (Caiani and Graziano, 2016: 248). The League proposed a new national strategy to replace its former policies of secessionism with nationalism. Salvini kept the League's populist, anti-systemic style while focusing on the issues perceived as problems throughout Italy, such as participation in the Euro and EU immigration policy. Thus, the "other" was no longer Rome but Brussels and EU institutions (Brunazzo and Gilbert, 2017: 631).

The League extends this "us"-"them" dichotomy to the European level in that the elites oppressing the people are the European ones. Secondly, its main focus is on domestic politicians perceived as puppets of these EU elites who have opened the frontiers of Italy and Europe to immigration. The League contrasts two Europes: the "Europe of peoples", who are wise and virtuous and the "Europe of institutions" that endanger the people's rights, particularly the European Commission, the European Central Bank. The League presents itself as the party embodying the voice of the people (Caiani and Graziano, 2016: 248-249).

The LN's nativist conception of the people was exclusionist and ethnocultural. Under Salvini, the League has kept its strong anti-immigration rhetoric and policies, emphasizing "our people first" while also referring to Islam as a threat to Christian identity (Ivaldi, Lanzone, and Woods, 2017: 363). Since Salvini became its leader, its use of "the people" has started to refer to all Italians. In one speech in 2015, Salvini apologized for the party's earlier hostile, antisouthern rhetoric, and emphasized that they were all Italians (cited by Ivaldi, Lanzone, and Woods, 2017: 362). This transformation from a regionalist to a populist radical right party is a unique case in European politics.

Salvini emphasizes that he is not against the EU but merely wants another type of Europe, although he never clarifies what kind of Europe it is (Brunazzo and Gilbert, 2017: 625-626). The League has become gradually more right-wing, 
18 with a xenophobic, anti-immigrant, Islamophobic attitude that brings it closer to European populist radical right parties (Fella and Ruzza, 2013: 42). Accordingly, it has formed closer interactions with other populist radical right parties, especially France's Front National (currently National Rally, NR). The similarities include not only Euroscepticism but also their anti-immigrant positions (Brunazzo and Gilbert, 2017: 635).

Salvini emphasised that the party wanted to transform Europe on behalf of its citizens. In an interview with Time on September 4, 2018, he stated that "changing Europe is a big goal". When asked "would you like to blow up the EU?" by referring to his interview at Le Figaro, he answered, "On the contrary, I think that history will entrust us with the role of saving European values... We are working to re-establish the European spirit that has been betrayed by those who govern this union". He claimed: "We want to change things from within" (Time, 13 September 2018). On 8 April 2019, Salvini launched his campaign to forge a far-right alliance as the informal leader of Europe's far-right. He emphasised that "it should be a government of the people" while claiming that "our target is to win and change the rules of Europe" (The Guardian, 8 April 2019).

The League won 28 seats in the 2019 EP elections, twice as many as its coalition partner M5S (Wallis, 2019). In his victory speech, Salvini stated that "not only is the League the first party in Italy, but also Marine Le Pen is the first party in France, Nigel Farage is the first party in the UK... It is the sign of a Europe that is changing" (The Guardian, 29 May 2019). Salvini then withdrew from Italy's coalition government to trigger snap elections to win a majority. However, he was instead ousted by an unexpected new coalition between the Democratic Party (PD) and M5S, under the leadership of the Prime Minister, Giuseppe Conte.

\section{THE FIVE STAR MOVEMENT (M5S)}

The M5S emerged in 2007 with large demonstrations in several Italian cities organized by Beppe Grillo, known as a stand-up comedian and political satirist. Grillo's blog formed the first basis of the movement (Franzosi, Marone, and Salvati, 2015: 109-110). In 2009, the movement was formalized as M5S. In the 2016 municipal elections, M5S's candidate for Rome's mayor was elected while M5S gained 32\% of the votes to become the largest party in the 2018 general elections (Bassini, 2020: 205-207).

M5S was established as an anti-party movement in reaction to the claimed inability of traditional parties to solve the citizens' problems. To differentiate itself, M5S described itself as a "non-party" (Bassini, 2020: 207). M5S has a clear anti-establishment and anti-elite position, which is one of the main characteristics of populism. M5S may be defined as populist in claiming that it represents an undifferentiated "people" against corrupt elites while Grillo's leadership may be characterized as charismatic. He prefers to use direct communication through social media and in person at public gatherings (Fella and Ruzza, 2013: 50).

M5S's ideological position cannot be clearly classified (Kneuer, 2018: 13) since its members do not define themselves as right or left, but adopt a fuzzy position. 
Gianfreda and Carlotti (2018) describe M5S as a "pure populist party" without a host ideology. According to Coticchia and Vignoli (2020: 531), however, M5S may be perceived as closer to a "left-libertarian party".

M5S criticizes Italy's traditional political and economic system, and the mainstream media from a strongly anti-establishment position while demanding greater participation for citizens through direct democracy. For M5S, social media is the central instrument for communication and mobilization (Kneuer, 2018: 13) while it sees direct "internet democracy" as a substitute for representative democracy. According to M5S, it is necessary to rewrite Italy's constitution to change the country and give it back to the people (Ivaldi, Lanzone, and Woods, 2017: 369).

Unlike other populist parties, however, M5S does not refer to the "people" as a nation (Franzosi, Marone, and Salvati, 2015: 112). Instead, Grillo emphasises that his party is a "movement of common citizens", a collection of small people, such as "workers, retirees and small entrepreneurs" who work to "pay for the salary of politicians" (cited by Ivaldi, Lanzone, and Woods, 2017: 362).

The M5S is critical of the EU and Euro, in particular by opposing the austerity measures. Its Euroscepticism, which is more "strategic" than ideological (Franzosi, Marone, and Salvati, 2015: 109-118), became more obvious before the 2014 EP elections (Corbetta and Vignati, 2014: 53-57). According to Caiani and Graziano (2016: 255), the party's 2014 election manifesto defined "us" as Italy while referring to "them" as the ECB, IMF, World Bank, the EU.

For the 2014 EP election campaign M5S announced "Seven Points for Europe", focusing on EU-imposed austerity measures since 2011. This "strategic Eurosceptic position" was confirmed by the party's attitudes in the EP. M5S MEPs have usually voted closer to pro-EU parties, particularly the Greens (Franzosi, Marone, and Salvati, 2015: 123). It is challenging for M5S to avoid clarifying its ideological position, especially to find allies in Europe. Thus, it is different from the League, which usually collaborates with other populist radical right parties.

Whereas the League emphasizes an ethno-cultural conception of the people and rejects pluralism, M5S focuses on grassroots democracy and new channels of direct participation through the internet and social media. While the League is a typical nativist populist party, it also supports economic nationalism whereas M5S may be defined as post-ideological populist, with no clear ideological attachment (Ivaldi, Lanzone, and Woods, 2017: 370-371). In the last EP elections (2019), 14 MEPs were elected from M5S without attachment to any EP political group (MEPs, 2020). The League has pioneered the newly formed Identity and Democracy (ID) group.

\section{THE ANALYSIS OF THE INTERVIEWS}

\section{Populism in Italian Politics: The League and M5S}

Most of the interviewees argued that populism is already part of Italian politics especially after Silvio Berlusconi. Interviewee 9 (2018), for example, claimed that Berlusconi was a populist, and that all Italian politics may be defined as populist 
to some extent, especially since the 1990s. The rise of populism in global politics and Europe's economic and migration crises have provided ideal circumstances for populism to spread, leading to the formation of the coalition government of two populist and Eurosceptic parties after Italy's last elections in 2018.

Interviewee 18 (2018), argued that "Italy is a country where populism was born in Europe; it is the land of populism". There has been an explosion of populism electorally in recent years, although it had long existed within Italian politics, but suppressed by the two mainstream parties. Interviewee 10 (2018) suggested that Italy has had populist parties in government before in that Umberto Bossi, former leader of the LN, was part of Berlusconi's centre-right coalition. FI was also a populist party while Salvini currently uses a populist discursive style... Bossi used the rhetoric of "we" the northern people against Rome's elite while Salvini has shifted this concept to "we, the normal people of Italy" against "the rest".

All the interviewees agreed that the League is a populist party while most also see M5S as a populist party. As Interviewee 3 (2018) put it, "I don't have any doubt defining the League as a populist party; the M5S is completely unique". Interviewee 5 (2018) argued that there are different degrees of populism and adding that, except some small parties, all of Italy's parties include some elements of populism. Interviewee 9 (2018) argued that the League is a populist radical right party, whereas "5SM is an ambiguous party that combines elements of left and right-wing populism".

Thus, nearly all interviewees agreed that populism is not a new phenomenon in Italian politics; rather, especially since Berlusconi, it is one of its main characteristics. The interviewees defined the League as a populist radical right party, especially under Salvini's leadership. Most also defined M5S as a populist party, although it has unique and fuzzy characteristics in ideological terms.

\section{Growing Fusion of Populism and Euroscepticism in Italy}

The interviewees mostly emphasized that the EU is generally seen as an external anchor to solve Italy's social and economic problems. All the interviewees argued that Italy has been one of the most pro-European countries in the EU. The main turning point was the economic and migration crises, which triggered the rise of populism and Euroscepticism.

As Interviewee 22 (2018) noted, "the EU is seen as an external anchor". She emphasized that "since the beginning of the 1990s, there has been a gradual decline in the level of support for the EU ... which accelerated with the financial crisis".

Interviewee 17 (2018) stated that over time, however, "Italians started to think that this idea of fitting Italy into a European straight jacket does not work" (Interviewee 17, 2018).

Nearly all the interviewees emphasized that the turning point in the rise of Euroscepticism was the economic crisis, although it accelerated further after the migration crisis. Interviewee 6 (2018) claimed that "Italy is leaning towards soft Euroscepticism". He argued that, although M5S has a strongly Eurosceptic identity, its supporters are in favour of remaining in the EU and the Euro. He 
added that the research from 2009-2014 showed that M5S took many anti-EU initiatives especially before the 2014 EP elections, even proposing a referendum about leaving the Euro. However, in the 2018 national electoral campaign, M5S downplayed anti-EU issues because prominent party officials realized that this was controversial among its voters, with only a minority rejecting the EU.

Interviewee 7 (2018) argued that since the EU is considered as the main actor of austerity politics, Italians blame it for forcing the government to commit to these politics. He also noted that the negative effects of globalization are also attributed to Europeanization. For Interviewee 22 (2018), the "League is very hard Eurosceptic" whereas M5S are "confused Eurocritics". Interviewee 18 (2018) argued that although both parties are hard Eurosceptic, they changed their discourse after taking power, and denied that they wanted to leave the EU.

Interviewee 3 (2018) pointed out that M5S stated after taking power that "the President would be sure that M5S isn't an anti-European movement". Interviewee 12 (2018) claimed that M5S was anti-European, and had wanted a referendum on Euro membership. However, once in government, they had significantly moderated their ideas. He claimed that the League still wanted to leave the Euro, but could not say it openly while in power. Interviewee 12 (2018) claimed that M5S is less Eurosceptic, and does not share the League's nationalism.

According to Interviewee 15 (2018), since its transformation into the League, the party has become more Eurosceptic. Both the League and the M5S have adopted the rhetorical solution of declaring that "we are pro-Europe, but not this Europe". However, the content and characteristics of this new EU desired by both parties remains unclear.

According to Interviewee 7 (2018), M5S even collected signatures to organize a referendum on the Euro. However, this would not be legal in Italy, so the Constitutional Court might stop it. In contrast, during the last national election campaign, Di Maio tried to reassure the financial markets and European institutions that Italy would not breach European rules, and had no intention to leave the EU. Interviewee 7 (2018) noted that "the M5S is divided on European issues ... but the League is more cohesive on its Euroscepticism". Thus, several interviewees argued that when the League and M5S came to power, they became softer Eurosceptics, especially M5S.

The second factor triggering rising Euroscepticism in Italy was the migration crisis. Interviewee 10 (2018) argued that the economic crisis was the turning point, another important factor is the migration crisis. He emphasized that Italians felt like left abandoned in the face of the influx of refugees.

Italy has also seen a rise in "horizontal Euroscepticism", focusing on France. Both the MS5 and the League regularly engage anti-Macron discourse. Interviewee 16 (2018) mentioned a rise in anti-France discourse, particularly against Macron. This increasing horizontal Euroscepticism towards France was reflected in the statements of Luigi di Maio about supporting French yellow vest protests and the impact of French colonization in Africa on irregular immigration to Europe.

Interviewee 9 (2018) pointed out that Euroscepticism has become fused with populism recently, in that people now see the corrupt elite as based in Brussels or Frankfurt rather than Rome. 
According to Interviewee 22 (2018), "the migration issue was felt so strongly because there was an economic crisis". In explaining the rise of populism and Euroscepticism, Interviewee 21 (2019) noted an increase in inequalities that generate much anger because social and economic policies remain unsolved at both national and European levels, coupled with widespread corruption in the political system. Interviewee 3 (2018) argued that anti-elite rhetoric of the League reflects its populist approach while its emphasis on anti-EU elite rhetoric reflects its Euroscepticism.

In sum, especially since the economic and migration crises, Italy's problems have been Europeanized. The anti-establishment, anti-elite position of the League and M5S are reflected at a European level. "Horizontal Euroscepticism" has spread in Italy too since the migration crisis and before the last EP elections in 2019, especially towards France and Macron specifically.

\section{The Role of the League and M5S in European Politics}

Under Salvini's leadership, the League has collaborated with other populist radical right parties, especially the NR before the last EP elections. Its campaign was based on anti-migration policies and "standing up" against Brussels (Quirk, 2020: 72).

According to Interviewee 21 (2019), populist radical right parties no longer favour leaving the EU; instead, they want to conquer it. Interviewee 8 argued that the League is much more collaborative than M5S since Salvini is creating a sovereigntist coalition. Interviewee 16 (2018) argued that the League is collaborating with the NR and the Freedom Party of Austria (FPÖ) to form a group united by anti-immigration attitudes to transform Europe. They share a common discourse that Europe's culture is fading away due to the "invasion" of immigrants. In short, these populist radical right parties share Euroscepticism and anti-immigrant policies, which bring them together in a reflection of an increasing fusion of populism and Euroscepticism.

All the interviewees agreed that M5S seems somewhat isolated in Europe because of its unique characteristics. For Interviewee 4 (2018), the main challenge is that "they have to decide where to locate themselves along the ideological spectrum". Interviewee 6 (2018) noted that the "peculiarity of M5S is one of the reasons for its international isolation". He added that their main EP ally was UKIP, which recently became the Brexit party, although they do not actually have much in common. Interviewee 5 (2018) reported that M5S's EP voting record in the previous EP term indicates that it is highly similar to the Democratic Party (PD)'s among Italian parties while least similar to UKIP. Interviewee 17 (2018) noted that, they prefer to avoid taking sides on many issues, which makes it more challenging for them to collaborate with other EP parties. In the new EP, M5S MEPs are currently unattached to any group. 
Table 1. Comparison between the League and M5S in terms

of Populism and Euroscepticism

\begin{tabular}{|c|c|c|}
\hline & The League & The Five Star Movement (M5S) \\
\hline Euroscepticism & $\begin{array}{l}\text { *Hard Euroscepticism } \\
{ }^{*} \text { Currently without a discourse and policy } \\
\text { on leaving the Euro and the EU, but } \\
\text { transforming the EU. } \\
\text { *Horizontal Euroscepticism (towards } \\
\text { France, particularly towards Macron) }\end{array}$ & $\begin{array}{l}\text { *Heterogeneous } \\
{ }^{*} \text { Transformation from hard Euroscepticism } \\
\text { to soft Euroscepticism. (Currently without } \\
\text { a discourse on leaving the Euro and the } \\
\text { EU) } \\
\text { *Strategic Euroscepticism, (in certain } \\
\text { periods for strategic reasons) } \\
\text { *Horizontal Euroscepticism } \\
\text { (towards France, particularly towards } \\
\text { Macron) }\end{array}$ \\
\hline Populism & $\begin{array}{l}\text { *Transformation from a regionalist } \\
\text { populist to a populist radical right party. }\end{array}$ & $\begin{array}{l}\text { *Populist (anti-establishment, anti-elite, } \\
\text { anti-globalisation) }\end{array}$ \\
\hline $\begin{array}{l}\text { Left-right } \\
\text { spectrum }\end{array}$ & $\begin{array}{l}\text { *Populist radical right } \\
\text { (with unique regionalist background) }\end{array}$ & $\begin{array}{l}\text { *Prefers not to clarify its ideological } \\
\text { stance (Fuzzy, fluid party) }\end{array}$ \\
\hline Nationalism & *Nationalist & *Not nationalist, more inclusive. \\
\hline Leadership & $\begin{array}{l}\text { *Strong leadership } \\
\text { *Main visible and influential political } \\
\text { figure Matteo Salvini }\end{array}$ & $\begin{array}{l}\text { * Main political figure and strong visible } \\
\text { leader at the beginning: Beppe Grillo } \\
{ }^{*} \text { Grillo more behind the scenes in recent } \\
\text { years. }\end{array}$ \\
\hline Nativism & $\begin{array}{l}\text { *Nativist } \\
\text { (First focusing on Padania, northern Italy, } \\
\text { as LN, then focusing on all Italy and } \\
\text { Italians as the League). }\end{array}$ & *No \\
\hline $\begin{array}{l}\text { Definition of the } \\
\text { "People" }\end{array}$ & $\begin{array}{l}\text { *Ethno-cultural definition } \\
\text { *Exclusivist towards immigrants } \\
\text { (especially African and Muslim } \\
\text { immigrants). }\end{array}$ & $\begin{array}{l}\text { *More inclusive but unclear about who is } \\
\text { the "people". }\end{array}$ \\
\hline Xenophobia & $\begin{array}{l}\text { *Yes (Some xenophobic discourse } \\
\text { although denied.) }\end{array}$ & *No \\
\hline Islamophobia & $\begin{array}{l}\text { *Yes (Stronger scepticism about } \\
\text { integration of Muslim immigrants.) }\end{array}$ & *No (not an issue for M5S) \\
\hline The "Other" & $\begin{array}{l}\text { *The "other" was the south of Italy and } \\
\text { Rome for NL. } \\
\text { *Others include immigrants, refugees, } \\
\text { and EU elites for the League. }\end{array}$ & $\begin{array}{l}\text { *Anti-establishment } \\
\text { *Anti-elite (including EU elites, particularly } \\
\text { Macron) }\end{array}$ \\
\hline $\begin{array}{l}\text { Collaboration } \\
\text { with other } \\
\text { Political Parties in } \\
\text { Europe }\end{array}$ & $\begin{array}{l}{ }^{*} \text { Very active } \\
{ }^{*} \text { Close collaboration with other populist } \\
\text { radical right parties (especially with NR). }\end{array}$ & *Unique and mostly alone \\
\hline
\end{tabular}




\section{The League and The M5S Before the 2019 European Elections}

During the 2019 European election campaign, populist radical right parties were very proactive to increase their influence at the EP to transform the EU. Interviewee 10 (2018) argued that Italy's mainstream parties have tried to copy both the rhetoric and issues emphasised by populist parties. However, as Interviewee 10 (2018) pointed out, "it is always the original that is preferred by the electorates".

Cooperation among the populist radical right increased before the last European elections. Salvini, for example, implemented a "strategy of creating an alliance of anti-immigration European populist parties" (Moschella and Rhodes, 2020: 117). As Interviewee 2 (2018), put it, "for us it is a big opportunity... to cooperate with every Eurosceptic party to change this Europe, to break the big alliance of EPP and Socialists". He emphasized that "we would like to change this Europe, especially for economic issues, migration policy, and protecting traditional values".

Interviewee 6 (2018) predicted that the situation was more critical for M5S since it had peaked electorally in the last general election. Therefore, improving on this record would be very difficult. He also noted that European elections usually influence domestic politics in Italy, which was realised when the League became Italy's biggest party in the last European elections, then withdrew from the coalition government.

Regarding the coalition between M5S and the League, Interviewee 6 (2018) argued that their common denominator is anti-austerity policies, although they also share populist characteristics as anti-establishment and Eurosceptic parties. Their coalition government was perceived by most of the interviewees as unstable.

Thus, all the interviewees predicted that populist radical right-wing parties would do well in the 2019 European elections while some claimed that this would also influence Italian politics. The results did indeed influence Italian politics by leading to the collapse and replacement of the ruling coalition between M5S and the League.

In the 2019 European elections, support for the League rose from $6.2 \%$ in 2014 to $34.3 \%$ whereas support for M5S declined from $21.2 \%$ to $17 \%$ (The Local, 27 May 2019). Le Pen and Salvini's parties' MEPs joined forces with antiimmigration parties across Europe to create ID (The Guardian, 13 June 2019).

Europe's radical right currently has 10\% of MEPs, compared with 5\% in the previous parliament. ID is led by Marco Zanni, who is an MEP from the League (The Guardian, 13 June 2019). Although the influence of the populist radical right has increased in the EP following the latest European elections, it is still limited compared to Europe's mainstream parties.

\section{CONCLUSION}

Euroscepticism has already become part of mainstream European politics; given Europe's ongoing economic and political crises, it may well consolidate its 
position. As McDonnell and Werner (2019: 1773) argue, the 2008 economic crisis provided an external shock that encouraged the populist radical right parties to harden their Eurosceptic positions.

Italy has moved from being a Europhile to Eurosceptic country since the Maastricht Treaty (Quirk, 2020: 70). This change was triggered particularly by the economic crisis and later the migration crisis. The EU, which has faced economic and migration crises, is one of the main targets and the "other" for European populist parties (Franzosi, Marone, and Salvati, 2015: 116).

Taggart and Szczerbiak (2013: 34) argue that the cases of the League and the M5S also prove that "government participation has the effect of tempering the policy of Eurosceptic parties". According to McDonnell and Werner (2019: 1775), Salvini made clear that his party wishes to reform the EU from within and no longer prioritizes exiting the Eurozone. On the other hand, populist radical right parties usually have a more consistent anti-immigrant position.

After the last European elections, Mudde (2019) claimed that the victor was the radical right rather than populism. Mudde (2019) concluded, "Populism is dead, long live the far right!"

Italian politics has been most affected by the growing fusion of populism and Euroscepticism, with various kinds of populist and Eurosceptic parties taking power in recent years. While the League has transformed itself into a typical populist radical right party, M5S has remained a populist party that avoids any clear ideological position. Both are anti-elite, anti-establishment, and Eurosceptic. They also share a "horizontal Euroscepticism" towards France, particularly towards Macron. This may influence European politics and the future of the EU project more strongly in the coming years, as was already observed in the last European elections.

All the interviewees emphasized that populist parties, particularly the League and M5S, have increased their influence in Italian politics because none of the mainstream parties can solve society's problems, especially since the economic and the migration crises.

After the last European elections, Salvini withdrew the League from the coalition as he was expecting to push for snap elections while his party's popularity was high. However, under the leadership of Giuseppe Conte, a law professor, a new coalition government was formed between M5S and PD (The Guardian, 9 September 2019). The sustainability of this new coalition government is questionable, especially after the recent COVID-19 pandemic, which has severely affected Italy socio-economically. If the current government cannot solve Italy's socio-economic problems, then the League may maintain or even increase its influence in Italian and European politics. EU policies towards Italy have become much more important, especially since the pandemic. Greater solidarity with Italy and other southern members of the EU are crucial to halt the drift towards Euroscepticism and populism. If solutions can be found for Italy's socio-economic problems by the mainstream parties, by increasing the level of support of the EU and solidarity among its member states, then the drift towards further Euroscepticism and populism may be resisted. 
Acknowledgements: I would like to thank to Prof. Giovanni Orsina, Director of Luiss School of Government and Prof. Sergio Fabbrini, Dean of the Political Science for giving me the chance to do this fieldwork for my research during my stay when I was a visiting professor at Luiss University in fall 2018. I would like to thank to Prof. Raffaele Marchetti and my other colleagues at Luiss University for their support and collaboration during my stay. I would like to thank to the interviewees for their useful insights about the research, anonymous referees for their constructive comments and the editors of Tripodos for their collaboration during the review and publication process of this article.

Selcen Öner (selcen.oner@eas.bau.edu.tr) is working as Assoc. Prof. Dr. at Bahçeşehir University (Istanbul) at the Department of Political Science and International Relations. She was a lecturer at Jean Monnet Module "Turkey-EU Cooperation against New Security Threats", and she had been its coordinator in 2014-2015. She was a visiting professor at Luiss University in Rome in fall 2018. She was a visiting scholar at Free University of Brussels Institute for European Studies, University of Aalborg and Free University of Berlin, and IBEI at Pompeu Fabra University. Her research interests include European identity, Turkey-EU relations, EU migration and asylum policy, and populist radical right parties in European politics. Her book Turkey and the European Union: The Question of European Identity was published by Lexington Publication in 2011.

\section{References}

Bardi, Luciano (2014). "Political Parties, Responsiveness and Responsibility in Multi-level Democracy: The Challenge of Horizontal Euroscepticism". European Political Science, 13, pp. 352-364.

Bassini, Marco (2020). "Rise of Populism and the Five Star Movement Model: An Italian Case Study". In: Delledonne, Giacomo; Martinico, Guiseppe; Monti, Matteo, and Pacini, Fabio (eds.). Italian Populism and Constitutional Law: Strategies, Conflicts and Dilemmas. London: Palgrave Macmillan, pp. 199-221.

Brunazzo, Marco and Gilbert, Mark (2017). "Insurgents Against Brussels: Euroscepticism and the Right-wing Populist Turn of the Lega Nord since 2013". Journal of Modern Italian Studies, 22 (5), pp. 624-641.
Caiani, Manuela and Graziano, Paolo R. (2016). "Varieties of Populism: Insights from the Italian Case". Italian Political Science Review, 46 (2), pp. 243-267.

Corbetta, Piergiorgio and Vignati, Rinaldo (2014). "Direct Democracy and Scapegoats: The Five Star Movement and Europe". The International Spectator, 49 (1), pp. 53-64.

Coticchia, Fabrizio and Vignoli, Valerio (2020). "Populist Parties and Foreign Policy: The Case of Italy's Five Star Movement". The British Journal of Politics and International Relations, 22 (3). DOI: <10.1177/13691481209228 08>.

Elman, Colin (2008). "Symposium on Qualitative Research Methods in Political 
Science". The Journal of Politics, 70 (1), pp. 272-274.

Fella, Stefano and Ruzza, Carlo (2013). "Populism and the Fall of the Centre-Right in Italy: The End of the Berlusconi Model or a New Beginning?". Journal of Contemporary European Studies, 21(1), pp. 38-52.

Franzosi, Paolo; Marone, Francesco, and Salvati, Eugenio (2015). "Populism and Euroscepticism in the Italian Five Star Movement". The International Spectator, 50 (2), pp. 109-124.

Gerring, John (2004). "What Is a Case Study and What Is It Good For?". American Political Science Review, 98 (2), pp. 341-354.

Gienfreda, Stella and Carlotti, Benedetta (2018). "The Different Twins". Italian Political Science, 13 (2), pp. 45-63.

Hooghe, Liesbet and Marks, Gary (2007). "Introduction: Sources of Euroscepticism". Acta Politica, 42 (2-3), pp. 119-127.

Inglehart, Ronald F. and Norris, Pippa (August 2016). "Trump, Brexit and The Rise of Populism: Economic Have-nots and Cultural Backlash". Harvard Kennedy School. Faculty Research Working Paper Series.

Ivaldi, Gilles; Lanzone, Maria Elisabetta, and Woods, Dwayne (2017). "Varieties of Populism across a Left-Right Spectrum: The Case of The Front National, the Northern League, Podemos and Five Star Movement". Swiss Political Science Review, 23 (4), pp. 354-376.

Kneuer, Marianne (2018). "The Tandem of Populism and Euroscepticism: A Comparative Perspective in the Light of the European Crises". Contemporary Social Science, pp. 26-42. Available at: <https://doi.org/10.1080/215820 41.2018.1426874>.

Leconte, Cecile (2015). "From Pathology to Mainstream Phenomenon: Reviewing the Euroscepticism Debate in Research and Theory". International Political Science Review, 36 (3), pp. 250-263.

McDonnell, Duncan (2006). "A Weekend in Padania: Regionalist Populism and the Lega Nord". Politics, 26 (2), pp. 133-139.
McDonnell, Duncan and Werner, Annika (2019). "Differently Eurosceptic: Radical Right Populist Parties and Their Supporters". Journal of European Public Policy, 26 (12), pp. 1761-1778.

MEPs (2020). European Parliament official website. Available at: <https://www.europarl. europa.eu/meps/en/search/advanced?country Code $=$ IT\&groupCode $=2970>$. Accessed $6 \mathrm{Au}-$ gust 2020 .

Moschella, Manuela and Rhodes, Martin (2020). "Introduction". Contemporary Italian Politics, 12 (2), pp. 112-125.

Mudde, Cas (2004). "The Populist Zeitgeist". Government and Opposition, 39(4), pp. 541-563.

-. (2007). Populist Radical Right Parties in Europe. Cambridge: Cambridge University Press.

-. (28 May 2019). "The Far Right May Not Have Cleaned Up, But Its Influence Now Dominates Europe". The Guardian. Available at: <https://www.theguardian.com/ commentisfree/2019/may/28/far-righteuropean-elections-eu-politics $>$. Accessed 15 December 2020.

Mudde, Cas and Kaltwasser, Cristobal Rovira (2018). "Studying Populism in Comparative Perspective: Reflections on the Contemporary and Future Research Agenda". Comparative Political Studies, 51 (13). Available at: <https:// doi.org/10.1177/0010414018789490>.

Norris, Pippa (2020). "Measuring Populism Worldwide". Harvard Kennedy School, Faculty Research Working Paper Series. Available at: <file:///C:/Users/VAIO/Downloads/ RWP20-002_Norris.pdf>

Quirk, Jessica (2020). "Italy and Euroscepticism: Political Uncertainty Gives Way to Temporary Political Relief". Australian and New Zealand Journal of European Studies, 12 (1), pp. 67-76.

Taggart, Paul (1998). “A Touchstone of Dissent: Euroscepticism in Contemporary Western European Party Systems". European Journal of Political Research, 33 (3), pp. 363-388. 
Taggart, Paul and Szczerbiak, Aleks (2013). "Coming in from the Cold? Euroscepticism, Government Participation and Party Positions on Europe". Journal of Common Market Studies, 51 (1), pp. 17-37.

The Guardian (8 April 2019). "Matteo Salvini Launches Campaign to Forge Far-right Alliance". Available at: <https://www.theguardian. com/world/2019/apr/08/matteo-salvinilaunches-campaign-to-forge-far-rightalliance>. Accessed 27 September 2019.

The Guardian (29 May 2019). "Brexit Party in Talks to Join Far-right Group in EU Parliament". Available at: <https://www.theguardian.com/politics/2019/may/29/brexitparty-said-talks-to-join-far-right-group-in-euparliament>. Accessed 14 October 2019.

The Guardian (13 June 2019). "MEPs Create Biggest Far-right Group in EP". Available at: $<$ https://www.theguardian.com/world/2019/ jun/13/meps-create-biggest-far-right-groupin-european-parliament>. Accessed 9 January 2020.

The Guardian (9 September 2019). "New Italian Government Wins Vote of Confidence in Lower Parliament". Available at: <https:// www.theguardian.com/world/2019/sep/09/ italys-pm-coalition-will-renew-citizens-faithin-government>. Accessed 12 February 2020.

The Local (27 May 2019). "The Biggest Winners and Losers in Italy's EU Election Results". Available at: <https://www.thelocal. it/20190527/winners-losers-italy-eu-electionresults>. Accessed 15 October 2019.

Time (13 September 2018). "We Want to Change Things from Within: Italy's Matteo Salvini on His Goal to Reshape Europe". Available at: <https://time.com/5394207/matteosalvini-time-interview-transcript-full/>. Accessed 27 September 2019.

Wallis, Emma (29 May 2019). "What the European Parliament Election Results Could Mean for Migration". Features. Available at: $<$ https://www.infomigrants.net/en/author/ emma\%20wallis/>.

\section{Expert and Elite Interviews}

Interviewee 1, Luiss University, Rome, 2018. Interviewee 2, Member of the League, Italian Chamber of Deputies, Rome, 2018.

Interviewee 3, University of Florence, Florence, 2018.

Interviewee 4, Scuola Normale Superiore, Florence, 2018.

Interviewee 5, University of Pisa, Pisa, 2018.

Interviewee 6, Luiss University, Rome, 2018.

Interviewee 7, University of Sapienza, Rome, 2018.

Interviewee 8, Luiss University, Rome, 2018.

Interviewee 9, European University Institute, Florence, 2018.

Interviewee 10, Niccolo Cusano University, Rome, 2018.

Interviewee 11, Luiss University, Rome, 2018.

Interviewee 12, Journalist, Il Fatto Quotidiano, Rome, 2018.

Interviewee 13, European Council on Foreign Relations (ECFR) Rome Office, Rome, 2018. Interviewee 14, Luiss University, Rome, 2018.

Interviewee 15, Luiss University, Rome, 2018.

Interviewee 16, Institute of International Affairs, (IAI), Rome, 2018.

Interviewee 17, Luiss University, Rome, 2018.

Interviewee 18, University of Sapienza, Rome, 2018.

Interviewee 19, University of Milan, Skype interview, 2019.

Interviewee 20, University degli Studi della Tuscia and Metropolitan City of Rome, Rome, 2018.

Interviewee 21, Member of European Parliament (MEP) at Group of Progressive Alliance of Socialists and Democrats, Skype interview, 2019.

Interviewee 22, Institute of International Affairs, (IAI), Rome, 2018. 